\title{
Discussion on Provincial Evaluation Results of Maternal Mortality in Terms of Preventability: Commission Decision Differences in Konya
}

(D) Yasemin DURDURAN, ${ }^{a}$

(D) Sema SOYSAL,

(D) Mustafa BAȘARAN, ${ }^{\mathrm{C}}$

(1) Çetin ÇELIK, ${ }^{d}$

(D) Ali ACAR, ${ }^{e}$

(D) Canan DOĞAN, ${ }^{\dagger}$

(D) Hüsnü Murat KAYA, ${ }^{\dagger}$

(D) Şule iZGi, ${ }^{\dagger}$

(D) Hasan ÖZNAVRUZ

\section{Departments of}

apublic Health,

${ }^{b}$ Medical Education and Informatics,

eObstetrics and Gynecology,

Konya Necmettin Erbakan University

Meram Faculty of Medicine,

'Clinic of Obstetrics and Gynecology,

Private Medova Hospital,

'Department of Obstetrics and

Gynecology,

Selçuk University Faculty of Medicine,

fPublic Health Directorate,

Konya

Received: 12.10.2017

Received in revised form: 27.03.2018

Accepted: 19.04.2018

Available online: 31.08 .2018

Correspondence:

Yasemin DURDURAN

Konya Necmettin Erbakan University

Meram Faculty of Medicine,

Department of Public Health,

Konya, TURKEY

ydurduran@gmail.com

Copyright (C) 2018 by Türkiye Klinikleri

\begin{abstract}
Objective: The objective of this study was to investigate the risk factors of maternal mortality in Konya province, as well as the preventability of deaths in cases where the central and local commissions differed in their decisions. Material and Methods: Maternal mortality between 2009 and 2014 in the Konya province was screened for the cases, where the central and local Maternal Mortality Investigation Commissions gave different decisions. These differences pertain to whether the deaths were 'preventable' or 'not-preventable', differences in the first, second and third delay models, and indirect, direct and incidental deaths. The data were evaluated electronically along with a descriptive statistical analysis, differences in the decisions and compliance in the mortality rates were evaluated. Results: The median age of the deceased mothers was 28 (2144 ) years and $83.3 \%$ of the mothers had at least one mortality risk factor. While the overall maternal mortality rate was $36.7 \%$ within the first $48 \mathrm{~h}$ after birth, the rates were highest within the first $48 \mathrm{~h}$ after birth (26.7\%) and between the 1st and 42nd day after birth (26.7\%) in indifferently assessed cases. The cause in $30 \%$ of all deaths and $33.3 \%$ of deaths with differential assessments was postpartum hemorrhage, as per the results of central Maternal Mortality Investigation Commissions. The decisions of the central and local commissions differed in terms of preventability, delay models or death classification in $50 \%$ of the deaths. Taken together, the compliance between central and local decisions was not precise in investigating maternal mortality. Conclusion: The first $48 \mathrm{~h}$ after birth and the postpartum period are particularly critical. The causes of death, particularly postpartum hemorrhage, should be thoroughly investigated. We recommend periodic re-evaluations of cases where different decisions were made, in order to lower the rate of preventable maternal mortality.
\end{abstract}

Keywords: Maternal mortality; preventability; Konya

$\mathrm{M}$ aternal death refers to death during pregnancy or within 42 days after termination of pregnancy, regardless of the duration and site of the pregnancy, from non-incidental reasons which are aggravated by the state or duration of pregnancy. ${ }^{1}$ According to the Health Statistics Yearbook (2014), the maternal mortality rate is 15.9 in 100,000 in Turkey and 9 in 100,000 in the western Anatolian region. According to the World Health Statistics, the annual maternal mortality in Turkey has declined by 20\% between 1990 and 2013, a testament to the healthcare infrastructure of this country. ${ }^{2}$

Most maternal deaths are preventable and the statistics of maternal mortality are one of the indicators of socio-economic development of any country. The health system of a country is responsible for investigating the 
factors affecting maternal deaths and their preventability, and make new regulations on the basis of the findings. According to the National Maternal Mortality Study, $61.6 \%$ of maternal deaths have one or more preventable factors. ${ }^{3}$ In order to lower the rate of preventable maternal deaths, therefore, the underlying causes of changes in maternal mortality around the world have to be identified, and in the light of the current research, future predictions and course of action can be determined.4-8 Maternal deaths are assessed by both the local commission and the central commissions established in the Ministry of Health under the Maternal Mortality Tracking and Evaluation Program in our country. ${ }^{9,10}$

The aim of this study was to determine the risk factors of maternal deaths, and investigate the compliance between the evaluations of the central (Turkish Public Health Agency Maternal Mortality Review Commission) and local (Konya Maternal Mortality Review Commission) commissions regarding the preventability of these deaths in Konya. The preventability factors were assessed in terms of local functioning, medical methods, and health policy with the aim of supporting the efforts of the next Maternal Mortality Review Commission studies, and indirectly increasing the compliance between the commissions.

\section{MATERIAL AND METHODS}

This study carried in the form of file scanning, out in the province of Konya between February-May 2015. Konya is an important metropolitan city of Central Anatolia and has a high density of hospitals. Data were obtained from the maternal mortality records at the Konya Public Health Directorate Child, Adolescent and Women Health Branch Directorate. The Konya Public Health Directorate and the local ethics committee granted permission for the study. Data of the demographic characteristics, mortality risk factors, late detection, number of prenatal follow-ups (healthy pregnancy follow-up consists of 4 follow-ups), type of delivery, time of death and reasons were collected for each subject. ${ }^{11}$
The focus of our study was on those maternal deaths that occurred between 2009-2014 in which the decisions of the Central and Local Maternal Mortality Review Commission were different. After obtaining the data enumerated above, the Maternal Mortality files were reviewed for the second time, and information on the purpose of the scanning was re-evaluated by the researchers. The decisions of the two commissions regarding preventability, delay models, and death classification were assessed. The first, second and third delay models are defined as delays in deciding to receive health care, reaching the organization, and receiving appropriate treatment respectively. ${ }^{12-15}$ Death classification includes direct and indirect maternal mortality. Direct mortality refers to deaths resulting from obstetrical complications during pregnancy, childbirth and postnatal period, medical interventions or negligence, or a combination of any of the above. Indirect maternal mortality refers to deaths due to an illness or disease that occurred before or during pregnancy and are thus a physiological effect of pregnancy, and not due to obstetrical influence. ${ }^{16}$ Taken together, differences in the decisions of the local and central commissions were compared for preventable and not preventable, first, second and third delay models, and direct and indirect incidental deaths. Statistical analysis was performed with the SPSS program (IBM SPSS Statistics, Sürüm 21.0 Armonk, NY: IBM Corp.). Cohen's Kappa statistic was used to evaluate the compliance between central and local decisions, and descriptive statistics of other parameters. ${ }^{17,18}$

\section{RESULTS}

The median age of the 30 mothers who had died was 28 (21-44) year and 16 (53,3\%) year were primary school graduates (Table 1 ). The median number of pregnancies was 3 (1-6) and that of live births was $2(0-4)$. There was at least one known mortality risk factor in 25 cases (83.3\%), and 17 $(56.7 \%)$ harbored multiple risk factors. The most common risk factors were frequent pregnancies with more than 2-year intervals $(n=9,30 \%)$ and chronic diseases ( $\mathrm{n}=7,23 \%)$ (Table 2). According to the guidelines of the Ministry of Health prena- 


\begin{tabular}{|c|c|c|}
\hline \multicolumn{3}{|c|}{$\begin{array}{l}\text { TABLE 1: Demographic and clinical characteristics of } \\
\text { all maternal deaths }(n=30) .\end{array}$} \\
\hline Variable & & $n(\%)$ \\
\hline \multirow[t]{2}{*}{ Age } & under 35 years of age & $24(80.0)$ \\
\hline & Aged 35 and above & $6(20.0)$ \\
\hline \multirow[t]{4}{*}{ Education status } & Illiterate & $4(13.3)$ \\
\hline & Primary school graduate & $16(53.3)$ \\
\hline & Secondary school graduate & $6(20.0)$ \\
\hline & Graduated from high school and above & $4(3.3)$ \\
\hline \multirow[t]{2}{*}{ Residence } & City Center & $12(40.0)$ \\
\hline & Town & $18(60.0)$ \\
\hline \multirow[t]{4}{*}{ Number of pregnancy } & 1 pregnancy & $8(26.7)$ \\
\hline & 2 pregnancies & $4(13.3)$ \\
\hline & 3 pregnancies & $11(36.7)$ \\
\hline & 4 and above pregnancies & $7(23.3)$ \\
\hline \multirow[t]{3}{*}{ Number of living children } & $1-2$ children & $18(60.0)$ \\
\hline & 3 children and above & $8(26.7)$ \\
\hline & None & $4(13.3)$ \\
\hline \multirow[t]{3}{*}{ Number of live birth } & None & $4(13.3)$ \\
\hline & $1-2$ live births & $18(60.0)$ \\
\hline & 3 live births and above & $8(26.7)$ \\
\hline \multirow[t]{2}{*}{ Number of stillbirths } & None & $19(63.3)$ \\
\hline & 1-2 stillbirths & $11(36.7)$ \\
\hline \multirow[t]{3}{*}{ Number of miscarriage } & None & $21(70.0)$ \\
\hline & 1 miscarriage & $6(20.0)$ \\
\hline & 2 miscarriages and above & $3(10.0)$ \\
\hline
\end{tabular}

tal care protocol, regardless of the risk factors, 21 (70\%) had first-trimester monitoring as per the gestational week, and 16 (64\%) with at least one risk factor had more than four follow-ups. One (3.3\%) deceased mother did not want to receive health care for follow-up, and 3 (10\%) pregnancies were detected late after the $14^{\text {th }}$ week. Considering all steps and follow-ups, 27 (90\%) of all deceased mothers and $22(88 \%)$ of those 25 who had a risk factor had at least four follow-ups, and the mean follow-up was 8 (2-19) for both groups. Fifteen $(65.2 \%)$ and $8(34.8 \%)$ of $23(76.7 \%)$ babies were delivered by cesarean section and vaginal route respectively. Twenty (66.7\%) deaths occurred during the postpartum period, while $2(6.7 \%)$ died at home. Eleven (36.7\%) maternal deaths occurred within the first $48 \mathrm{~h}$ after delivery (Figure 1). The reason for 9 (30\%) deaths was postpartum hemorrhage.

In terms of preventability, delay models and death classification, the compliance between the central and local decisions was lower (kappa=0009, $\mathrm{p}=0.961$ ) in the evaluation of maternal deaths. Central and local review committees differed in decision-making in terms of preventability, delay models or death classification in $15(50 \%)$ maternal deaths (Table 3), of which 5 (33.3\%) cases had been diagnosed with a chronic disease, and 3 (20\%) pregnancies were detected later than the detection week stated in the prenatal care protocol. Twelve (80\%) of those pregnancies concluded with birth, of which 7 (58.3\%) occurred via C-section and one ended in abortion. Of the 12 births, 6 (46.1\%) occurred in the state hospital, 3 in medical faculties $(23.1 \%), 2$ in a training-research hospital $(15.4 \%)$ and one in a private hospital (15.4\%). Of the 15 deaths, $12(80 \%)$ occurred in the medical faculties and the training-research hospitals. The highest number of deaths occurred within the first $48 \mathrm{~h}$ after delivery $(\mathrm{n}=4,26.7 \%)$ and between $7-42$ days after delivery $(\mathrm{n}=4,26.7 \%)$ (Figure 1$)$. Postpartum hemorrhage was the cause of 5 (33.3\%) of these deaths. Inadequate management of postoperative hemorrhage, follow-up problems with the ones experiencing chronic diseases, and inadequate postnatal care at primary care follow-up and hos-

\begin{tabular}{|c|c|}
\hline $\begin{array}{c}\text { TABLE 2: Risk factors in pregnancies of } \\
\text { evaluated mothers. }\end{array}$ & \\
\hline Risk Factors* ${ }^{*}$ & $n(\%)$ \\
\hline More frequent pregnancy than two years & $9(30.0)$ \\
\hline $\begin{array}{l}\text { Chronic disease presence (Chronic hepatitis B, hepatitis C carriage, } \\
\text { thalassemia carriage, Takayasu's arthritis, Goiter, CVS, ARF) }\end{array}$ & $7(23.3)$ \\
\hline$\geq 4$ pregnancy & $6(20.0)$ \\
\hline$>$ Aged 35 pregnancy & $6(20.0)$ \\
\hline The first-degree relationship between spouses & $4(13.3)$ \\
\hline Rh incompatibility & $3(10.0)$ \\
\hline \multicolumn{2}{|l|}{ Short stature, skeletal deformities } \\
\hline \multicolumn{2}{|l|}{$3(10.0)$} \\
\hline Hypertension & $2(6.6)$ \\
\hline Stillbirth, premature birth, LBW infants & $3(10.0)$ \\
\hline Old section, placenta previa & $5(16.6)$ \\
\hline Pregnancy without follow up & $1(3.3)$ \\
\hline
\end{tabular}




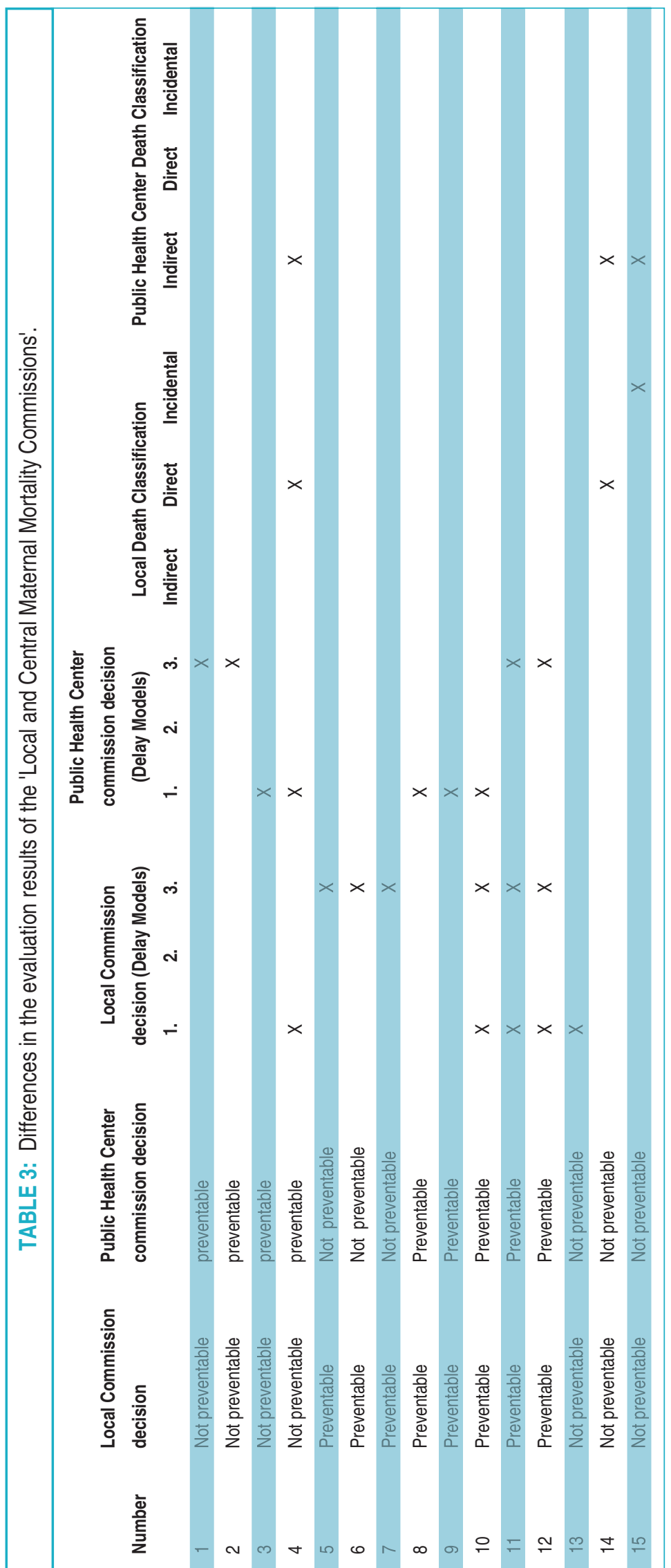

pitals were the most significant causes of death.

In terms of preventability decision: The Central Review Commission assigned 9 (60\%) and Local Review Commission assigned 8 (53.3\%) deaths out of the 15 as preventable. Four (26.7\%) of the cases were autopsied. In 7 (46.6\%) deaths, the decisions as to whether or not they were preventable were different between the two commissions. While 3 cases were assessed as preventable and not-preventable by the local and central commissions, respectively, the other 4 had the opposite assessment (Table 3).

Two of the cases assessed as notpreventable by the local commission and preventable by the central commission were due to postpartum hemorrhage, one was due to pulmonary embolism, and one was diagnosed differentially by the two commissions. One of the postpartum hemorrhage cases was assessed as not-preventable by the local commission on account of the conditions of the venue, while the central commission assessed it as preventable with the third delay. In the other postpartum hemorrhage case, the local commission ruled complications of pneumothorax and intracranial incidences as the causes of death, while the central commission attributed the death as the third delay due to lack of transfusion. The central commission assigned the pulmonary embolism death to the first delay due to non-compliance of the patient and her relatives to the recommendations of the institution. The cause of death in one case was diagnosed as DIC (disseminated intravascular coagulation) after HELLP (hemolysis, elevated liver enzyme levels, and low platelet levels) syndrome and preeclampsia by the 


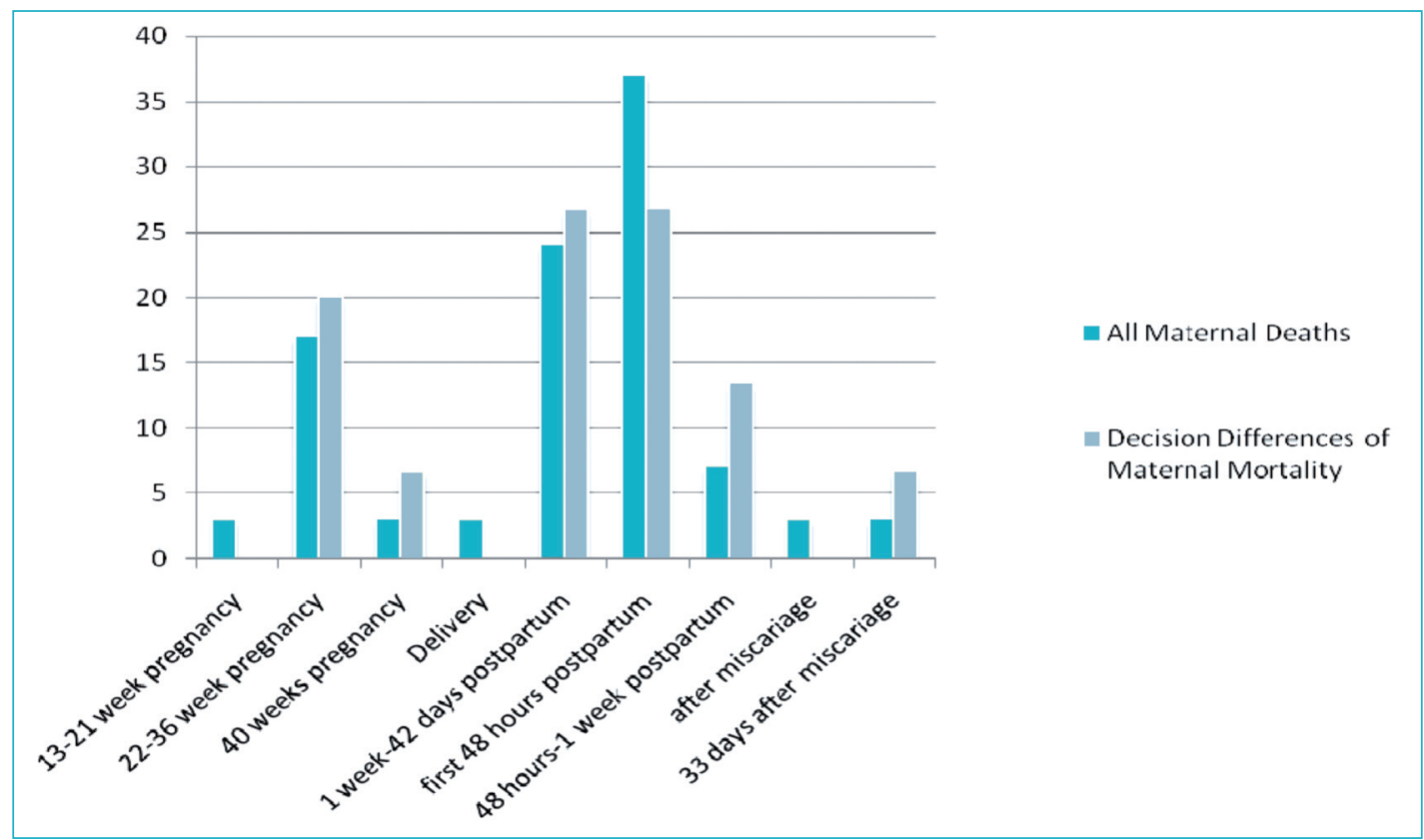

FIGURE 1: Periods in which maternal deaths occurred (all maternal deaths and decision differences of central/local commissions) (\%).

local commission, and due to pneumonia and sepsis by the central commission. In addition, the local commission considered the death to be direct while the central commission cited indirect maternal death. However, although the local commission assessed this death as not preventable they also acknowledged the first delay since the mother refused to come for pregnancy follow-ups.

Three deaths were assessed as preventable by the local commission and not-preventable by the central commission. Two of them were due to postpartum hemorrhage and one was due to venous thrombosis and neurofibromatosis. The local commission considered the postpartum hemorrhage cases as manageable and preventable by contemporary treatments and patient compliance. In the case of cortical venous thrombosis and neurofibromatosis, considering the fact that the patient was pregnant independently of other diseases, the local commission recommended carrying out all diagnostic and treatment procedures by the gynecology department. The maternal death that was assessed by both commissions as preventable with a third delay was transferred to judicial authorities, where an expert reported that 'there was no delay in intervening in the case' since death was due to amniotic fluid embolism.
In terms of delay models: Six (40\%) of the 15 maternal deaths assessed differentially by the two commissions had differences in terms of delay models, despite the same decision made by both commissions in terms of preventability (Table 3). In two cases, the local commission did not add any delay models but the central commission decided first delay since the mothers did not terminate pregnancy despite being informed of the risks due to chronic diseases. The local commission assessed three cases as first and third delay (local commission cited delay also for the hospital as they did not strictly follow-up on the chronic illness), while the central commission assessed one death as only first delay and two deaths as only third delay. Both commissions assessed one case that was due to postpartum hemorrhage and another that was due to rupture while waiting for $\mathrm{C}$-section as the third delay. The local commission also gave the first delay to the mother in both cases for being late to prenatal care. In one case with infective endocarditis, related sepsis and DIC that was assessed as not-preventable by both commissions, the fact that the mother was not compliant with the treatment of chronic illness and did not follow up with the authorities prompted the local commission to report the death as not-preventable in terms of the 
site but with the first delay as conception was not avoided.

In terms of death classification: Three cases were classified differentially by the two commissions. For two of those, the local commission classified one as direct and the other one as incidental, while the central commission classified both as indirect (Table 3). The death assessed as direct by the local commission occurred on the $33^{\text {rd }}$ day after abortion as a result of toxic shock syndrome after septic abortion/ARDS (acute respiratory distress syndrome)/multiple organ failure, but the central commission classified it as indirect maternal death due to pneumonia/sepsis/ARDS. Another death was assessed as incidental due to intracerebral hemorrhage after cesarean delivery by the local commission, and as indirect maternal mortality due to intracranial hemorrhage, sepsis and SIRS (systemic inflammatory response syndrome) by the central commission. The third death was assessed as direct maternal death due to DIC after HELLP syndrome and preeclampsia by the local commission, and as indirect death due to pneumonia and sepsis by the central commission.

\section{DISCUSSION}

Between 2009 and 2014, the maternal mortality rate declined from $18.4 / 100,000$ to $15.8 / 100,000$ in Turkey, and from $22.2 / 100,000$ to $11.3 / 100,000$ in Central Anatolia. As part of the Maternal Mortality Monitoring and Evaluation Program which has been carried out since 2007, maternal mortality is investigated by the Public Health Institution of Turkey and Department of Women and Reproductive Health in 81 cities of Turkey and the local commissions of those cities. ${ }^{9,10}$ The lack of a similar study in the literature on commission differences in maternal deaths may be due to differences in the maternal mortality assessment system in countries. However, there are studies indicating that an increase in records of maternal mortality rates has been observed in some developed countries as the International Classification of Diseases (ICD) 10 coding has begun to be used. ${ }^{7,19,20} \mathrm{We}$ evaluated maternal deaths that occurred between 2009 and 2014 in Konya, that were assessed differentially by the Local Maternal Mortality Review Commission and the Public Health Institution Maternal Mortality Review Commissions of Turkey. The focus of the study was to determine that factors which can prevent maternal deaths and offer recommendations to health workers on that basis.

According to the central commission, 9 of the 30 deaths were due to postpartum hemorrhage, 5 due to embolism, 3 due to sepsis, 2 due to hypertension and 11 were attributed variously to epilepsy, viral hepatitis, intracerebral hemorrhage due to an aneurysm, and tachyarrhythmia. Half of the mothers who died were primary school graduates, and the majority were residents of the peripheral districts. The median age of our cohort was similar to that in the study of Biri and his colleagues on maternal deaths in Ankara between 1997-2000, which reported a median age of 30 years (19-44). ${ }^{21}$ One-fifth of the deceased mothers in our study were older than 35 years, and were thus at a higher risk of adverse pregnancies. ${ }^{22,23} \mathrm{Ac}-$ cording to the Turkish National Maternal Mortality Study, the maternal mortality rate is $46.2 / 100,000$ between $35-39$ years, and increases to 99.6/100,000 between 40-44 years of age. ${ }^{3}$ Higher education levels can lead to advanced maternal age as women are focused on their careers. It may be therefore beneficial to educate the general public regarding the risk associated with pregnancy over the age of thirty-five, and the importance of regular pregnancy monitoring in any age group.

In our study, most of the deceased mothers harbored one or more risk factors for maternal mortality during their pregnancy, and two-thirds had more than one risk factor. The leading risk factors for maternal mortality are frequent pregnancies with at least 2-year intervals, pregnancies followed by chronic illness, more than 4 previous pregnancies, and age over 35 years. In our study, one-fourth of the mothers who died between 2009 and 2014, and one-third of the deaths that were assessed differentially had a diagnosed chronic disease. It is noteworthy that the percentage of chronic illness in the ones with decision difference was higher than in all maternal deaths. Only one of the deceased mothers did not want to receive 
health care for follow-up. According to the Turkish Demographic and Health Survey 2013 data, $2.7 \%$ of the pregnant women do not receive prenatal care. ${ }^{24}$ The high rate of risky pregnancies in the deceased mothers, and the presence of woman who refuse health care services strongly suggest the need for different methods to raise awareness about the importance of pregnancy follow-ups. An important finding of this study was that the percentage of the deceased mothers was higher than that of the live newborns. This has a negative long-term social impact due to motherless children and broken families. Therefore, social assessment of maternal deaths is also important.

When data from the primary, secondary, and tertiary care institutions were analyzed together, the rate of having a pregnancy follow-up suitable for the gestational week was found to be high. The average follow-up per pregnant woman in Turkey was 3.6 in 2009 and 4.3 in $2013 .{ }^{25}$ When risk factors for maternal mortality are taken into consideration, more frequent follow-ups are recommended, along with treatment in some cases. One notable point is that in all of the late detected maternal deaths, according to the detection week indicated in the prenatal care protocol, the decisions of the central and local commissions regarding the deaths were different.

Another highly significant point is that in half of the deaths due to $\mathrm{C}$-section (and $2 / 3^{\text {rd }}$ of the all deceased mothers had C-section), the decisions of the two commissions were different. According to the TDHS, the rate of C-sections were 37\% in 2008 and $48 \%$ in $2013 . .^{24,26}$ According to the Public Health Institution of Turkey, the percentage of cesarean births in all births was $42.7 \%$ in 2009 and $50.4 \%$ in 2013. ${ }^{25}$ Although we cannot make a significant association between $\mathrm{C}$-section and maternal mortality in this study, the high rate of $\mathrm{C}$-section in the deceased mothers is noteworthy. Studies indicate an increase in cesarean deliveries in recent times, and a lot of attention has therefore been focused on the possible causes of this increase and its effects on maternal deaths. ${ }^{27-29}$ Since C-sections were overrepresented in our study, we recommend that the type of delivery be emphasized in follow-ups of a healthy pregnancy as well. The studies should be conducted to determine whether $\mathrm{C}$-sections are correlated with higher maternal mortality and if yes, steps should be enforced to reduce cesarean deliveries.

Two-thirds of all maternal deaths and half of the deaths which were assessed differentially by the local and central commissions occurred during the postpartum period, with no significant differences seen in the time of deaths. In the 1992-1993 National Maternal Mortality study in Egypt, maternal mortality was found to be $35.5 \%$ during the postnatal period, $39.2 \%$ at birth, and $25.7 \%$ during pregnancy. ${ }^{30}$ More than half of the deaths that were assessed differently occurring in state hospitals, mostly in medical faculties and training-research hospitals. Different sites of childbirth and maternal death indicates that the mother was referred to another institute or physician. The Ministry of Health Postpartum Care management guidelines identify the referral criteria and The Ministry of Health Emergency Obstetric Care Management Guidelines identify possible cases requiring referral during follow-up in emergency situations. ${ }^{31,32}$ The Local Emergency Health Services Coordination Commission decides how the referrals will be made and to which health institutions.

The percentage of maternal deaths due to postpartum hemorrhage that received different assessments was similar to the overall percentage of deaths due to postpartum hemorrhage. Hemorrhage, pulmonary embolism, infections, hypertensive diseases, cardiomyopathy, cardiovascular diseases, and noncardiovascular medical conditions contributed to $10-13 \%$ of maternal mortality between 1998 and 2005 in the United States. ${ }^{20}$ In our study, hemorrhage was a significant cause of maternal mortality. Despite the guidelines and standardized protocols for postoperative hemorrhage management of the Ministry of Health Postpartum Hemorrhage Management, it is surprising that the local and central commissions made different decisions regarding the percentage of maternal deaths. Apart from the level of training and skill of the investigating team, differences in decisions regarding postpartum hemorrhagic maternal deaths 
can also be due to the different site evaluations. Therefore, it is necessary for practitioners to periodically revise the standard protocols pertaining to postoperative hemorrhage management.

Non-compliance between the decisions of local and central commissions, in terms of preventability, delay models, and classification were seen in half of the maternal deaths. In $50 \%$ of these deaths, the disagreement was regarding preventability. Furthermore, even when both commissions made the same decision in terms of preventability, differences arose regarding the delay models. Finally, in three maternal deaths, both commissions differed in terms of death classification (direct, indirect or incidental). In a study by Biri et al. ${ }^{21}$, the cause of death was not detected in 18 of 58 cases of maternal mortality. This suggests shortcomings in not only the diagnosis but also in the implementation of the Maternal Death Prevention Program. In a study by Esen Melez et al., the autopsy results for pregnancy-related maternal deaths between 2003 and 2009 were evaluated to determine the underlying causes. ${ }^{33}$ However, we studied the cases recorded as a part of the Maternal Death Prevention Program, which were affected by different evaluations of the local and central commissions. The difference in the evaluation criteria of the two commissions may suggest different interpretations of the respective members due to different professional experiences. In addition, the local commission is usually better informed about the provincial conditions.

Some specific reasons for different decisions are the inability to obtain detailed medical histories of individual patients during the follow-up due to the high patient population, subjective assessment of postpartum vaginal bleeding that may delay management of postoperative bleeding, imparity between crisis management and postoperative hemorrhage protocols, unnecessary referrals that can potentially lead to delays in follow up, and possible lack of skills and/or confidence in the use of guidelines by the field doctors. These concerns are significant since births are more common in state hospitals and maternal deaths are more common in medical faculties and training-research hospitals.
Regular evaluations and studies and further training are needed to address the above limitations and to help reduce the number of preventable maternal deaths. We also recommend conducting simulated training of risky pregnancies for gynecology and obstetrics students, as well as in midwifery and nursing undergraduate training. Training the actively practicing doctors can also increase their knowledge, skills, and self-confidence in such cases. To prevent unnecessary delays, effective communication between the healthcare professionals should be implemented. An 'emergency obstetric care list' including the name and contact information of doctors and the work plan of the central teams can provide on-site support to these institutions instead of referring to another hospital.

In conclusion, the central and local commission members should regularly re-examine the cases that were assessed differently, in order to reach a consensus and identify the problem to help reduce future incidences of preventable maternal mortality.

\section{Source of Finance}

During this study, no financial or spiritual support was received neither from any pharmaceutical company that has a direct connection with the research subject, nor from a company that provides or produces medical instruments and materials which may negatively affect the evaluation process of this study.

\section{Conflict of Interest}

No conflicts of interest between the authors and / or family members of the scientific and medical committee members or members of the potential conflicts of interest, counseling, expertise, working conditions, share holding and similar situations in any firm.

\section{Authorship Contributions}

Idea/Concept: Yasemin Durduran, Sema Soysal, Mustafa Başaran; Design: Yasemin Durduran, Sema Soysal,Canan Doğan, Hüsnü Murat Kaya; ontrol/Supervision: Yasemin Durduran, Sema Soysal,Canan Doğan, Çetin Çelik; Data Collection and/or Processing: Ali Acar, Çetin Çelik, Sema Soysal, Mustafa Başaran, Şule İzgi; Analysis and/or Interpretation: Ali Acar, Yasemin Durduran, Sema Soysal, Çetin Çelik, Mustafa Başaran, Canan Doğan, Hüsnü Murat Kaya; Literature Review: Yasemin Durduran, Sema Soysal; Writing the Article: Yasemin Durduran, Sema Soysal, Çetin Çelik, Mustafa Başaran; Critical Review: Ali Acar, Çetin Çelik; References and Fundings: Canan Doğan, Hüsnü Murat Kaya, Şule İzgi, Hasan Öznavruz. 


\section{REFERENCES}

1. World Health Organization (WHO). Measuring maternal mortality. Trends in Maternal Mortality: 1990 to 2008. Geneva, Switzerland: WHO Press; 2010. p.4.

2. World Health Organization (WHO). World Health Statistics 2014. Geneva, Switzerland: WHO Press; 2014. p.180.

3. Hacettepe Üniversitesi Nüfus Etütleri Merkezi. Ulusal Anne Ölümleri Çalışması. T.C. Sağlık Bakanlığı Ana Çocuk Sağlığı ve Aile Planlaması Genel Müdürlügüü ve Avrupa Komisyonu Türkiye Delegasyonu. Ankara: Elma Teknik Basım Matbaacılık; 2005. p.267.

4. World Health Organization (WHO). Trends in maternal mortality: 1990 to 2010 WHO, UNICEF, UNFPA and The World Bank estimates. Genava, Switzerland: WHO Press; 2012. p.59.

5. Stanton C, Hobcraft J, Hill K, Kodjogbé N, Mapeta WT, Munene F, et al. Every death counts: measurement of maternal mortality via a census. Bull World Health Organ 2001;79 (7):657-64.

6. Ronsmans C, Graham WJ. Maternal mortality: who, when, where, and why. Lancet 2006;368(9542):1189-200.

7. Kassebaum NJ, Bertozzi-Villa A, Coggeshall MS, Shackelford KA, Steiner C, Heuton KR, et al. Global, regional, and national levels and causes of maternal mortality during 19902013: a systematic analysis for the Global Burden of Disease Study 2013. Lancet 2014;384(9947):980-1004.

8. Saucedo M, Deneux-Tharaux C, BouvierColle MH; Le Comité national d'experts sur la mortalité maternelle. [Maternal mortality in France, 2007-2009]. J Gynecol Obstet Biol Reprod (Paris) 2013;42(7):613-27.

9. T.C. Sağlık Bakanlığı Ana Çocuk Sağlığı ve Aile Planlaması Genel Müdürlügü. Anne Ölümleri Veri Sistemi. 2007/27 Sayllı Genelge; 2007. p.4.

10. T.C. Sağlık Bakanlığı Ana Çocuk Sağlığı ve Aile Planlaması Genel Müdürlüğü. 2007/27 Sayılı Genelgeye Ek Genelge 2007/57; 2007. p.2.

11. T.C. Sağlık Bakanlığı Türkiye Halk Sağlığı Kurumu. Doğum Öncesi Bakım Yönetim Rehberi. Sağlık Bakanlığı Yayın No: 924. Ankara: Türkiye Halk Sağlığı Kurumu Kadın ve Üreme Sağlığı Daire Başkanlığı; 2014. p.32.
12. United Nations Population Fund (UNFPA). Maternal Mortality Update 2002: A focus On Emergency Obstetric Care. New York: UNFPA; 2003. p.35.

13. Thaddeus $S$, Maine $D$. Too far to walk: maternal mortality in context. Soc Sci Med 1994;38 (8):1091-110

14. Combs Thorsen V, Sundby J, Malata A. Piecing together the maternal death puzzle through narratives: the three delays model revisited. PLoS One 2012;7(12):e52090.

15. Barnes-Josiah D, Myntti C, Augustin A. The "three delays" as a framework for examining maternal mortality in Haiti. Soc Sci Med 1998;46(8):981-93.

16. World Health Organization (WHO). Maternal Mortality in 2005: Estimates developed by WHO, UNICEF, UNFPA and The World Bank. Geneva, Switzerland: WHO Press; 2007. p.39.

17. Hayran M, Hayran H. Sağlık Araştırmaları İçin Temel İstatistik. Omega Araştırma. 1. Baskı. Ankara: Art Ofset Matbaacılık Yayıncılık; 2011.

18. KIlıç S. [Kappa test]. Journal of Mood Disorders 2015;5(3):142-4.

19. World Health Organization-1. International Statistical Classification of Diseases and Related Health Problems. 10 $0^{\text {th }}$ Revision. Volume 2. Geneva, Switzerland: WHO Press; 2010. p.189.

20. Berg CJ, Callaghan WM, Syverson C, Henderson Z. Pregnancy-related mortality in the United States, 1998 to 2005. Obstet Gynecol 2010;116(6):1302-9

21. Biri A, Öztürk J, Maral I. [Maternal deaths occured in hospitals in Ankara between 1997 and 2]. Turkiye Klinikleri J Med Sci 2002;22(2): 142-7.

22. T.C. Sağlık Bakanlığı Türkiye Halk Sağlığı Kurumu. Riskli Gebelikler Yönerim Rehberi. Sağlık Bakanlığı Yayın No: 926. Ankara: Türkiye Halk Sağlığı Kurumu Kadın ve Üreme Sağlığı Daire Başkanlığl; 2014. p.65.

23. Şekeroğlu M, Baksu A, İnce Z, Gültekin H, Göker N, Özsoy S. [Obstetric outcomes in adolescents and older pregnancies]. Swollen Etfal Hospital Medical Bulletin 2009;43(1):1-7.

24. Hacettepe Üniversitesi Nüfus Etütleri Enstitüsü. Türkiye Nüfus ve Saülık Araștırmas 2013. Hacettepe Üniversitesi Nüfus Etütleri
Enstitüsü, T.C. Sağlık Bakanlığı, TÜBiTAK. Ankara: Elma Teknik Basım Matbaaclık Ltd Şti; 2014. p.343.

25. T.C. Sağık Bakanlığı Sağlık Araştırmaları Genel Müdürlügü. Başara BB, Güler C, Yentür GK, editörler. Sağlık İstatistikleri Yıllığı 2013. Ankara: Sentez Matbaacilık ve Yayıncılık; 2014. p.163.

26. Hacettepe Üniversitesi Nüfus Etütleri Enstitüsü. Türkiye Nüfus ve Sağlık Araştırmas 2008. Hacettepe Üniversitesi Nüfus Etütleri Enstitüsü, T.C. Sağlık Bakanlığı Ana Çocuk Sağlığı ve Aile Planlaması Genel Müdürlüğü, Başbakanlık Devlet Planlama Teşkilat Müsteşarlığı ve TÜBITAK. Ankara: Hacettepe Üniversitesi Hastaneleri Basımevi; 2009. p.345.

27. Declercq E, Young R, Cabral H, Ecker J. Is a rising cesarean delivery rate inevitable? Trends in industrialized countries, 1987 to 2007. Birth 2011;38(2):99-104.

28. Barber EL, Lundsber LS, Belanger K, Pettker CM, Funai EF, Illuzzi JL. Indications contributing to the increasing cesarean delivery rate. Obstet Gynecol 2011;118(1):2938.

29. Marshall NE, Fu R, Guise JM. Impact of multiple cesarean deliveries on maternal morbidity: a systematic review. Am J Obstet Gynecol 2011;205(3):262.e1-8.

30. Patel DA, Burnett NM, Curtis KM. Maternal Health Epidemiology. Reproductive Health Epidemiology Series: Module 2. Atlanta, Georgia, USA: Department of Health and Human Services; 2003. p.71

31. T.C. Sağ ık Bakanlığı Türkiye Halk Sağlığı Kurumu. Doğum Sonu Bakım Yönetim Rehberi. Sağlık Bakanlığı Yayın No: 925. Ankara: Türkiye Halk Sağlığı Kurumu Kadın ve Üreme Sağ|ığı Daire Başkanlığı; 2014. p.44.

32. T.C. Sağlık Bakanlığı Ana Çocuk Sağlığı ve Aile Planlaması Genel Müdürlüğü. Doğum Öncesi Bakım Yönetim Rehberi. Sağlık Bakanlı̆ı̆ Yayın No: 924. Ankara: Türkiye Halk Sağlığı Kurumu Kadın ve Üreme Sağlığı Daire Başkanlığı; 2009. p.32.

33. Esen Melez I, Şahin E, Gürler AS, Melez DO, Şahin MF, Avşar A, et al. [Maternal death cases for which autopsies were performed in Istanbul]. Turkiye Klinikleri J Foren Med 2012;9(1):28-36 